\title{
Formation of the culture of social relations in students based on the development of their personal social experience
}

\author{
Formação da cultura de relações sociais nos alunos a partir do \\ desenvolvimento de sua experiência social pessoal
}

\section{Formación de la cultura de las relaciones sociales en los estudiantes a partir del desarrollo de su experiencia social personal}

\author{
Ekaterina Akishina $^{1}$ iD, Irina Wagner ${ }^{1}$ (D), Natalya Kurbatova² ${ }^{\text {iD }}$, Lyubov Savenkova ${ }^{3}$ iD \\ ${ }^{1}$ Institute of Art Education and Cultural Studies of the Russian Academy of Education, Moscow, Russia. \\ ${ }^{2}$ Academy of Watercolors and Fine Arts of Sergei Andriyaka, Moscow, Russia. \\ ${ }^{3}$ Institute of Art Education and Cultural Studies of the Russian Academy of Education, Moscow, Russia. \\ Corresponding author: \\ E.M. Akishina \\ Email: ekaterina.m.akishina@mail.ru
}

How to cite: Akishina, E. M., Wagner, I. V., Kurbatova, N. V., \& Savenkova, L. G. (2022). Formation of the culture of social relations in students based on the development of their personal social experience. Revista Tempos e Espaços em Educação, 15(34), e17215. http://dx.doi.org/10.20952/revtee.v14i33.17215

\section{ABSTRACT}

The article presents provisions on the phenomenon of the personal socio-cultural experience of students and its role in the development of personality. The necessity and possibility of purposeful development of learners' personal experience of social relations in the conditions of an educational organization to form the culture of social relations in the educational process participants, as well as the cultural competencies of students, are substantiated. The dependence of the development of students' cultural competencies on the peculiarities of their personal experience of social relations is demonstrated; characteristics of some types of relevant experience are provided. A method for studying students' personal cultural experience as the fundamental component of their cultural competencies and the process of forming a culture of social relations in an educational organization is developed.

Keywords: Personal socio-cultural experience. Cultural competencies. Culture of social relations. Educational organization. Students' experience of social relations.

\section{RESUMO}

O artigo apresenta disposições sobre o fenómeno da experiência sócio-cultural pessoal dos estudantes e o seu papel no desenvolvimento da personalidade. A necessidade e possibilidade de desenvolvimento intencional da experiência pessoal de relações sociais dos alunos nas condições de uma organização educacional para formar a cultura das relações sociais nos participantes do 
processo educacional, bem como as competências culturais dos alunos, são substanciadas. É demonstrada a dependência do desenvolvimento das competências culturais dos estudantes das peculiaridades da sua experiência pessoal de relações sociais; são fornecidas características de alguns tipos de experiências relevantes. É desenvolvido um método de estudo da experiência cultural pessoal dos estudantes como componente fundamental das suas competências culturais e do processo de formação de uma cultura de relações sociais numa organização educativa.

Palavras-chave: Experiência sócio-cultural pessoal. Competências culturais. Cultura das relações sociais. Organização educativa. Experiência de relações sociais dos estudantes.

\section{RESUMEN}

El artículo presenta disposiciones sobre el fenómeno de la experiencia personal sociocultural de los alumnos y su papel en el desarrollo de la personalidad. Se fundamenta la necesidad y la posibilidad de un desarrollo intencionado de la experiencia personal de relaciones sociales de los alumnos en las condiciones de una organización educativa para formar la cultura de las relaciones sociales en los participantes del proceso educativo, así como las competencias culturales de los alumnos. Se demuestra la dependencia del desarrollo de las competencias culturales de los alumnos de las peculiaridades de su experiencia personal de relaciones sociales; se proporcionan las características de algunos tipos de experiencia relevante. Se desarrolla un método para estudiar la experiencia cultural personal de los estudiantes como componente fundamental de sus competencias culturales y del proceso de formación de una cultura de relaciones sociales en una organización educativa

Palabras clave: Experiencia personal sociocultural. Competencias culturales. Cultura de las relaciones sociales. Organización educativa. Experiencia de los alumnos en las relaciones sociales.

\section{INTRODUCTION}

The need to reconsider the theoretical approaches to the problem of developing cultural competencies in students to form a culture of social relations of participants in the educational process is due to the increasing need of Russian society in the positive dynamics of socio-cultural development, strengthening of the best traditions of national culture, the formation of a civilized, cultural, psychologically comfortable social space, and the establishment of new generations as carriers of Russian cultural values and full-fledged participants in the creative process of culture creation. The actualization of the stated research problem is simultaneously enhanced by the ambiguous trends of the modern global world and the new challenges of the time emerging in their context, including the aggravation of the social risks of socialization of the new generation in problem situations caused, in particular, by the pandemic and the crisis phenomena associated with it; increasing manifestations of aggression in the educational environment, the virtual space, and other spheres of modern society.

The prospects of Russia's socio-economic development in the face of the new challenges of the global society are determined by the quality of human resources, the formation of which occurs in the process of socialization of the new generations. Achieving the ideals of social development and creating a civilized, cultural, psychologically comfortable social space meeting the needs of the majority of Russian citizens is only possible if in the process of students' education and socialization, they develop relevant cultural competencies ensuring their establishment as the carriers of the values of Russian culture and full-fledged participants in the creative process of culture creation if they develop the need and readiness for self-realization in social practice for the good of society and the country's socio-economic development through bringing to life the values of Russian culture. 


\section{LITERATURE REVIEW}

In resolving the research objectives, we rely on the works of psychologists who note the presence of a certain set of qualities that constitute "the core of character", are determined primarily by the individual neurophysiological characteristics and environmental impacts in early childhood (B.M. Teplov, V.D. Nebylitsyn, A.E. Lichko, A.V. Zaporozhets), and present one of the most stable and constant personality characteristics (B.G. Afanasiev, I.S. Kon, A.E. Lichko). We also refer to the conclusions of L.I. Bozhovich that each age stage of a child's mental development "is characterized by a typical combination of external and internal circumstances of development, which generate an age-specific inner position of the child". The works of K.A. AbulkhanovaSlavskaia, B.G. Ananiev, N.V. Andrienko, E.A. Antsiferova, L.P. Bueva, L.S. Vygotsky, A.N. Leontiev, B.F. Lomov, and S.L. Rubinshtein offer the opportunity to examine the process of socialization as the objectification and appropriation of society's culture, to interpret the essence of the subject of socialization at the psychological and pedagogical level, in which the quality of a subject is defined by the system of relationships. Furthermore, we rely on sociological studies, which define experience as the leading psychological characteristic of personality in a specific social structure (I.S. Kon, A.G. Kharchev), unravel a person's social experience through the concept of "motivational background" (A.G. Zdravomyslov, G.F. Karvatskaia, A.N. Leontiev, V.N. Miasishchev, V.A. ladov); works in the field of social psychology, in which the essence of social experience is presented as a system of personal social relations (B.P. Parygin, A.V. Petrovskii); the works of psychologists focusing on the mechanisms of personal mental development, characterizing social experience as a definition of the subject themselves, on which their inner position depends (K.A. Abulkhanova-Slavskaia, A.G. Asmolov, L.I. Bozhovich, L.S. Vygotsky).

We also analyze thesis studies conducted in the past twenty years in the problem field of the formation of the culture of social relations of students and the development of their personal social experience. Herein, we have to note the interdisciplinary nature of this problem. The phenomenon of social relations is actively studied in philosophy, sociology, and psychology, which largely determines the vectors of the theoretical and methodological foundations of the formation of the culture of social relations in pedagogy. A sociological view of social relations is formed, same as in any other science, both in the large-scale methodological format of study of the phenomenon at the country-wide and regional levels and with respect to the particular aspects of the problem. In particular, I.V. Lukashonok (2005) examines the problem of institutionalization of new social relations in modern Russia; L.V. Stakhira (2002) considers informal social relations in the regional socio-economic structure; L.N. Vaneeva (1999) develops the problem of harmonization of social relations in regional communities, A.V. Chichkanov (2008) conducts a sociological analysis of social relations in contemporary Russian society, and so on. In a more narrow context, scholars consider such aspects as, for instance, trust in the system of social relations of the regional population (Bespartochnyy, 2012), etc.

Particular attention is paid to the scientific works focusing on the phenomenon of a person's social experience, for example, thesis works in philosophy including D.Yu. Dorofeev's "Philosophical anthropology as a phenomenology of life experience" (Dorofeev, 2000) and P.N. Kurlovich's "The role of the structure of personal experience in the comprehension of social existence" (Kurlovich, 2000). A special emphasis is also placed on pedagogical studies exploring the role of social experience in socialization and education and searching for new approaches to the development of the social experience of children and youth in association with the formation of the culture of social relations. The latter include "Formation of the social experience of high school students" by T.Yu. Utyamisheva (2014), "Pedagogical conditions for the formation of students' experience of positive social relationships" by A.I. Sapozhnikov (2000), "The theory and technology of adult education based on vitagenic (life) experience" by N.O. Verbitskaya (2002), "Didactic conditions for the formation of real-life experiences of students in the learning process" by N.V. Gogolev (2002), 
"Development of the life cognitive experience in the learning process of modern university students" by N.I. Solovyeva (2016), "Formation of the socio-ecological experience of schoolchildren in the educational process in a rural school: on the example of biology" by L.T. Belkov (2006), and more.

\section{METHODS}

The present study is conducted as part of the implementation of the scientific research project "Formation of cultural and cultural and creative competencies of students and teachers as a basis for the formation of the culture of social relations" (scientific advisor L.G. Savenkova) within the framework of the State Assignment of the Ministry of Education of the Russian Federation to the Institute of Art Education and Cultural Studies of the Russian Academy of Education for 2021. In our study, we pay special attention to the phenomenon of students' personal socio-cultural experience and the theoretical substantiation and research of its role in the development of students' cultural competencies and the formation of the culture of social relations in the subjects of the educational process. The present paper reports the results of a study using qualitative data collection methods. In particular, we analyze methodological approaches to the study of the phenomenon of children's socio-cultural experience, philosophical, culturological, sociological, psychological, and pedagogical works on the problem of developing cultural competencies in students and forming the culture of social relations in the subjects of the educational process, and modern studies in the context of the signified research problem.

At the first stage of the study, we conduct a contextual and comparative analysis of the ideas about the phenomena of personal socio-cultural experience of students, cultural competencies, and the culture of social relations of the subjects of the educational process outlined in the texts of Ph.D. and doctoral theses (selected from the works published in the last 10 years). The analysis employs the method of theoretical modeling of the educational environment as a nurturing social space that transmits to children the culture of social relations and provides for the expansion of students' relevant experience of social relations as a basic component of their cultural competencies. Based on the results of theoretical modeling, applied diagnostic methods are developed to continue the research at the empirical level, forming an empirical database on the experience of social relations as a determinant of the development of cultural competencies in students.

The second stage consists in the organization of a discussion of the problem with students, teachers, and experts. In the present paper, we provide the diagnostic method that we developed - the "Questionnaire 'MY PERSONAL CULTURAL EXPERIENCE?'” (Appendix 1), which allows the participants in educational relations to analyze their personal socio-cultural experience from the perspective of the problem of the formation of the culture of social relations, to assess its significance and express their opinion on the role and development of personal experience in the formation of the culture of social relations. The focus of our attention in this method is "cultural experience", i.e. positive experience related to the comprehension of culture, the experience of creative activity because it is this experience that we consider as a basic component of students' cultural competency and the formation of the culture of social relations in educational organizations.

The developed method is presented in full including the introductory and concluding words addressed to the interviewees.

\section{RESULTS AND DISCUSSION}

The conducted analysis of theoretical sources reveals that in the last decade, philosophical science has explored the phenomenon of social relations both at the methodological level (Izgarskaya, 2015; Katsai, 1999) and at the level of studying particular aspects of social relations, for 
instance, the aspects of informatization scrutinized in the study "Information communications and social relations" by A.Yu. Rusakov (2008) or the examination of justice as a principle of harmonization of social relations (Isanbayeva, 2010). In the context of the established research objectives, of interest are philosophical works examining the culturological and aesthetic aspects of social relations, in particular, the studies concerning the aesthetic cognitiveness of social relations (Shevchenko, 2003) and the culturological aspect of social and labor relations (Lukash, 2009). A.V. Katsai notes that the problem of social relations occupies one of the central places in social philosophy. The researcher indicates:

It is precisely social relations that present the It is precisely social relations that are the link that allows the theoretical study of society to reproduce the latter as an organic social totality in the interrelation of its main elements, moments, and sides. These aspects and moments are the activities of mastering the environment; the structures of everyday life or the forms of human life; the ways of human communication; social actors - individuals, social cells (groups, collectives), social subjects (castes, strata, classes, confessions); the forms of social consciousness; the striving for the emancipation of socially determined existence, etc. (Katsai, 1999, p. 28).

Of importance is also the researcher's view on the specifics of social relations, their special qualitative definition expressing the difference between human interaction with other people as a social type of the movement of matter and other types of such movement including other types of human interaction. A.V. Katsai refers to social relations as a specific universal phenomenon that penetrates all sides and spheres of society and is refracted and modified in each of them differently. At the same time, the phenomenon in question does not exist as a universal form or as a truly existent universal. A.V. Katsai (1999) argues that

There are no social relations "in themselves", as there is no society "in itself", a person "in themselves", etc. Even the great idealist Plato believed that the universal ideas - eidoses - exist in the real material world in the form of their separate individual copies, as imperfect individual incarnations. The same applies, in a twofold way, to social relations: on the one hand, they are a particular way of the existence of united people or a historically determined attributive form of their connection; and on the other hand, social relations are only one of a variety of relations between people in society who coexist together, along with one another, in the same place at the same time. (p. 33).

Of great importance for the formation of the philosophical-pedagogical basis for resolving the established research objectives is a set of philosophical studies that examine personality and the process of its socialization in the system of social relations. In her work "Social mechanisms for the formation of personal culture", T.N. Bespalova (2008) concludes that a methodological key to understanding the process of socialization is "the composition of a person's social experience conveyed by the mechanisms of socialization" (p. 9). The researcher suggests analyzing the composition of social experience /composition of culture/ in typological terms while taking as a starting point the concept of the social program of inheritance. T.N. Bespalova (2008) argues that

Human potential set by genetic factors translates into reality only based on effective implementation of the social program of inheritance, which by its mechanisms transmits the accumulated social experience from generation to generation ... This social experience of mankind from an axiological point of view represents the unity of the positive and the negative, the valuable and the anti-valuable, which forms the opposition of culture and anti-culture already in the composition of social life. The objective of socialization is to transmit to new generations, first of all, the achievements of culture, i.e. positive experience. (pp. 13-14). 
In modern conditions, when the education system shows a clear trend of standardization of the educational process, its content, and results, the presented provisions are of particular methodological significance. In designing the process of the formation of the culture of social relations in an educational organization, it is necessary to rely on this understanding of the specifics of social relations, provide the subjects of social relations with an opportunity for their singular and unique embodiment here and now, as specific participants in the educational process rather than as a model of the culture of social relationships between children and adults "in general". A logical continuation of the discussed methodological approaches is the design of dynamic targeted models of self-developing systems of the formation of the culture of social relations in educational organizations.

Literature analysis allows identifying the characteristics of social relations in contemporary Russian society and the mechanisms of their development and improvement. Specifically, A.V. Chichkanov (2008) notes that

social relations are formed in all types and areas of human activity - in labor, daily life, education, health, leisure, etc. with regard to the satisfaction of people's vital needs, the social status of the subjects of interaction, the opportunities to meet the vital needs of people and their ways of life, etc. Accordingly, it is customary to distinguish between socio-labor, sociostatus, socio-domestic, and other types of social relations. (p. 10).

The researcher's appeal to the category of "social relations" is facilitated by sociological theories that "develop the idea of the formation and evolution of social institutions based on the fundamental relations of social exchange existing in society. Social relations are characterized by the reproduction and improvement of individuals and social groups through the satisfaction of their vital needs" (Chichkanov, 2008, p. 19). Analysis of several methodological positions leads the scholar to several conclusions. First, Chichkanov concludes on the need for a creative combination of various principles and methods of social sciences in the process of studying social relations, primarily axiological methodology and the systemic approach. Second, he indicates the trends of social studies overcoming economic determinism and of the use of the principles of macro-social analysis of the effects of social forces, including the consideration of political, sociocultural, and other plans of social life, as well as the development of methods for their research and the generalization of the results obtained. Finally, the author concludes on the promising character of the conflictological component in studies of the system of social relations in modern Russia and the need for a model of development through contradictions and conflict, more specifically, through the technologies of their resolution (Chichkanov, 2008, p. 25).

The phenomenon of social relations has been a subject of research in pedagogical science as well, starting from the theoretical and methodological levels. In particular, studying the cultural appropriateness of education and the pedagogical experience of Russia in the 18th-20th centuries, A.P. Bulkin pays special attention to the category of social relations, their typologization, and their influence on education. The author substantiates the dependence of the place and role of the education system in society on the socio-cultural environment, the dynamics of which are conditioned, in turn, by the type of social relations. Bulkin $(2003$, p. 16) describes three such types: the first type - relations of personal dependence, the second type - personal independence based on material dependence, and the third type - free individuality based on the universal development of individuals.

Analysis of Bulkin's approaches to the typologization of the social relations that affect the development of the system of education, its objectives, and, consequently, the processes of personality development in the new generations clearly shows the need to typologize social relations in society not only as "external factors" affecting the educational system, but also the 
relationship of these types of social relations with those developing within the system, i.e. social relations in the educational environment between the subjects of the educational process. Comprehension of processes of the formation of the culture of social relations in the educational organization also demands identifying and characterizing the types and levels of formation of the culture of social relations, their features determined by students' age, and other factors, that is, typologizing social relations in the educational organization and the levels of formation of their culture.

The solution to this problem can be supported by the approaches to the structuring of social relationships offered by pedagogical research and the aspects of their study stated in these works.

There is a group of studies examining social relations in connection with a particular social sphere or type of educational organization. G.F. Arstangaleeva (2011) examines the formation of the culture of social interaction of students in the open educational space of a college. I.R. Gainutdinova (2010) develops the problem of forming the readiness of high school students to social interaction as a precondition of their socialization. Yu.P. Yablonskikh (2006) focuses on the child as a subject of social relations, studying the process of moral upbringing. N.V. Ivanova (2004) is designing the social space of relations in a preschool educational organization. A.A. Konokotin (2001) studies the formation of youth culture in the sphere of family and domestic relations, while E.I. Bairamova (2002) develops the problem of the formation of the professional and pedagogical orientation of a high school student's personality by means of social culture, and so on. Here we pay attention to the studies the problem field of which is consonant with the research objectives set by us.

Of special interest are, naturally, the conclusions of researchers on the essential characteristics of the culture of social relations or the culture of social interaction - analysis of research shows that these concepts are often used interchangeably and carry virtually the same meaning in many theses works. Meanwhile, both the community, society, or social group and the personality of a student and a teacher function as the carriers of the culture of social relations/interaction.

G.F. Arstangaleeva views the culture of social relations precisely as a qualitative characteristic of personality. According to the researcher, the culture of social interaction includes

the axiological, cognitive, activity, and personality components, which define the system of
social relations and socio-cultural values aimed at a person's interaction with society. The
culture of social interaction is manifested in relationships of different levels, specifically,
"student-student", "student-teacher", and "student-community", and has a major impact on
the development of a specialist in the process of their educational, extracurricular, and other
types of activities. (Arstangaleeva, 2011, p. 13).

The researcher also emphasizes the multifunctionality of the culture of social interaction, the integration of its educational, communicative, socialization, and professional functions. The culture of social interaction is characterized by G.F. Arstangaleeva (2011) as "a holistic, specially organized process of gradual change of the motivation, thinking, individual experience, and relationships of subjects in the educational process and society, which ensures the humanistic, value and meaning, and personal orientation of their interaction" (pp. 6-7). The study in question also provides substantiation for a method of forming the culture of social interaction in students, which discloses the features of its stages constituting the integrative integrity: the propaedeutic stage, during which the enrichment of "subject-subject relations, connections, positions of participants of interaction in the open educational space" is activated (Arstangaleeva, 2011, p. 11), the technological, as part of which "the diversity of the use of upbringing influences and resources of the open educational space and society" is ensured (Arstangaleeva, 2011, p. 11), and the 
transformational, which "orients on the comprehension of the subjective results of activity, behavior, and communication" (Arstangaleeva, 2011, p. 11).

Realizing these provisions in association with the subject approach, we will develop the presented provisions with regard to the pedagogical practice of forming a culture of social relations in an educational organization in the direction of not only passing positive socio-cultural experience to the new generations but also forming new positive socio-cultural experience in the younger generations, recognizing their subjective role in the large-scale process of culture creation. In each particular micro-society, educational space, in relation to each particular child, this methodology actualizes a child's personal socio-cultural experience, as well as the socio-cultural experience of children and adults' community, the quality and nature of which is of primary importance in the formation of cultural competencies of students and the culture of social relations in the educational organization as a whole.

\section{CONCLUSION}

The study provides the theoretical substantiation of the need for and possibility of purposeful development of students' personal experience of social relations in the conditions of an educational organization to form the culture of social relations in participants of the educational process, and the cultural competencies of students. The conditionality of the development of cultural competence of students by the peculiarities of their personal experience of social relations is revealed. The study also provides a characteristic of some types of relevant experience, the expansion of which in the process of education and upbringing will improve the effectiveness of the development of students' cultural competencies, as well as ensure the formation of the culture of social relations in the subject of the educational process in educational organizations. A method is developed for studying students' personal cultural experience as a fundamental component of their cultural competencies and the process of the formation of the culture of social relations in an educational organization.

Authors' Contributions: Akishina, E. M.: conception and design, acquisition of data, analysis and interpretation of data, drafting the article, critical review of important intellectual content. Wagner, I. V.: conception and design, acquisition of data, analysis and interpretation of data, drafting the article, critical review of important intellectual content. Kurbatova, N. V.: conception and design, acquisition of data, analysis and interpretation of data, drafting the article, critical review of important intellectual content. Savenkova, L. G.: conception and design, acquisition of data, analysis and interpretation of data, drafting the article, critical review of important intellectual content. All authors have read and approved the final version of the manuscript.

Ethics Approval: Not applicable.

Acknowledgments: The article was prepared within the framework of the State Assignment of the Ministry of Education of the Russian Federation to the Federal State Budget Scientific Institution "Institute of Art Education and Cultural Studies of the Russian Academy of Education" No. 073-00008-21-01 for 2021.

\section{REFERENCES}

Arstangaleeva, G. F. (2011). Formirovanie kultury sotsialnogo vzaimodeistviia studenta v otkrytom obrazovatelnom prostranstve kolledzha [Formation of students' culture of social interaction in the open educational space of a college]. Summary of a Ph.D. thesis in pedagogy. South-Ural State University, Chelyabinsk, 26 p.

Bairamova, E. I. (2002). Formirovanie professionalno-pedagogicheskoi napravlennosti lichnosti starsheklassnika sredstvami sotsialnoi kultury [Formation of the professional and pedagogical orientation of the personality of high school students by means of social culture]. Ph.D. thesis in pedagogy. Kazan State Pedagogical University, Kazan, 250 p.

Belkov, L. T. (2006). Formirovanie sotsialno- ekologicheskogo opyta shkolnikov v obrazovatelnom protsesse selskoi shkoly: na materiale biologii [Formation of the socio-ecological experience of schoolchildren in the educational 
process in a rural school: on the example of biology]. Ph.D. thesis in pedagogy. Belgorod State University, Belgorod, $305 \mathrm{p}$.

Bespalova, T. N. (2008). Sotsialnye mekhanizmy formirovaniia kultury lichnosti [Social mechanisms for the formation of personal culture]. Summary of a Ph.D. thesis in philosophy. Nizhny Novgorod State University of Architecture and Civil Engineering, Nizhny Novgorod, 25 p.

Bespartochnyy, D. B. (2012). Doverie v sisteme sotsialnykh otnoshenii naseleniia regiona [Trust in the system of social relations of the population of the region]. Ph.D. thesis in sociology. Russian State Social University, Moscow, 155 p.

Bulkin, A. P. (2003). Kulturosoobraznost obrazovaniia. Pedagogicheskii opyt Rossii XVIII-XX vv. [Cultural appropriateness of education. Pedagogical experience of Russia in the 18th-20th centuries]. Summary of a doctoral thesis in pedagogy. Moscow State Linguistic University, Moscow, $47 \mathrm{p}$.

Chichkanov, A. V. (2008). Sotsialnye otnosheniia v sovremennom obshchestve (Sotsiologicheskii analiz) [Social relations in modern society (Sociological analysis)]. Summary of a doctoral thesis in sociology. Russian Academy of Public Administration under the President of the Russian Federation, Moscow, 51 p.

Dorofeev, D. Yu. (2000). Filosofskaia antropologiia kak fenomenologiia zhiznennogo opyta [Philosophical anthropology as a phenomenology of life experience]. Ph.D. thesis in philosophy. St.-Petersburg State University, St.-Petersburg, 195 p.

Gainutdinova, I. R. (2010). Formirovanie gotovnosti starsheklassnikov k sotsialnomu vzaimodeistviiu kak uslovie ikh uspeshnoi sotsializatsii [Formation of high school students' readiness for social interaction as a condition for their successful socialization]. Ph.D. thesis in pedagogy. Ulyanovsk State University, Ulyanovsk, 319 p.

Gogolev, N. V. (2002). Didakticheskie usloviia formirovaniia realnogo zhiznennogo opyta uchashchikhsia v protsesse obucheniia [Didactic conditions for the formation of real-life experiences of students in the learning process]. Ph.D. thesis in pedagogy. Tula State Pedagogical University named after L.N. Tolstoy, Tula, $153 \mathrm{p}$.

Isanbayeva, S. D. (2010). Spravedlivost kak printsip garmonizatsii sotsialnykh otnoshenii [Justice as a principle of harmonization of social relations]. Ph.D. thesis in philosophy. Bashkir State University, Ufa, 149 p.

Ivanova, N. V. (2004). Teoriia i praktika postroeniia sotsialnogo prostranstva otnoshenii v doshkolnom obrazovatelnom uchrezhdenii [Theory and practice of building a social space of relationships in a preschool educational institution]. Doctoral thesis in pedagogy. Vyatka State University for the Humanities, Kirov, 390 p.

Izgarskaya, A. A. (2015). Prostranstvo sotsialnykh otnoshenii v geopoliticheskom i mirosistemnom izmereniiakh [The space of social relations in the geopolitical and world-systemic dimensions]. Summary of a doctoral thesis in philosophy. Siberian Federal University, Krasnoyarsk, 45 p.

Katsai, A. V. (1999). Sotsialnye otnosheniia. Filosofsko-metodologicheskii aspekt [Social relations. The philosophical and methodological aspect]. Ph.D. thesis in philosophy. Moscow State Pedagogical University, Moscow, 145 p.

Konokotin, A. A. (2001). Stanovlenie iunosheskoi kultury v sfere semeino-bytovykh otnoshenii [The formation of adolescent culture in the sphere of family and domestic relations]. Ph.D. thesis in pedagogy. Lipetsk State Pedagogical University, Lipetsk, 178 p.

Kurlovich, P. N. (2000). Rol struktury lichnogo opyta v postizhenii sotsialnogo bytiia [The role of the structure of personal experience in the comprehension of social existence]. Ph.D. thesis in philosophy. Kazan National Research Technological University, Kazan, 168 p.

Lukash, A. V. (2009). Kulturologicheskii aspekt sotsialno-trudovykh otnoshenii [The culturological aspect of social and labor relations]. Ph.D. thesis in philosophy. Omsk State Railway University, Omsk, 167 p.

Lukashonok, I. V. (2005). Institutsionalizatsiia novykh sotsialnykh otnoshenii v sovremennoi Rossii [Institutionalization of new social relations in contemporary Russia]. Summary of a doctoral thesis in sociology. Rostov State University, Rostov-on-Don, $51 \mathrm{p}$.

Rusakov, A. Yu. (2008). Informatsionnye kommunikatsii i sotsialnye otnosheniia [Information communications and social relations]. Doctoral thesis in philosophy. Herzen State Pedagogical University of Russia, St. Petersburg, 311 p.

Sapozhnikov, A. I. (2000). Pedagogicheskie usloviia formirovaniia u shkolnikov opyta pozitivnykh sotsialnykh otnoshenii [Pedagogical conditions for the formation of students' experience of positive social relationships]. Ph.D. thesis in pedagogy. Stavropol State University, Stavropol, 155 p.

Shevchenko, L. N. (2003). Problema esteticheskoi kognitivnosti sotsialnykh otnoshenii [The problem of aesthetic cognitiveness of social relations]. Ph.D. thesis in philosophy. Kuban State University, Krasnodar, 143 p. 
Solovyeva, N. I. (2016). Razvitie zhiznennogo poznavatelnogo opyta v protsesse obucheniia studentov sovremennogo vuza [Development of the life cognitive experience in the learning process of modern university students]. Ph.D. thesis in pedagogy. Altai State Pedagogical University, Barnaul, 295 p.

Stakhira, L. V. (2002). Neformalnye sotsialnye otnosheniia v regionalnoi sotsialno-ekonomicheskoi strukture [Informal social relations in the regional socio-economic structure]. Summary of a Ph.D. thesis in sociology. Khabarovsk State Technical University, Khabarovsk, 22 p.

Utyamisheva, T. Yu. (2014). Formirovanie sotsialnogo opyta starsheklassnikov [Formation of social experience of high school students]. Ph.D. thesis in pedagogy. Orenburg State University, Orenburg, 205 p.

Vaneeva, L. N. (1999). Garmonizatsiia sotsialnykh otnoshenii v regionalnom sotsiume [Harmonization of social relations in a regional community]. Ph.D. thesis in sociology. Mordovian State University, Saransk, 175 p.

Verbitskaya, N. O. (2002). Teoriia i tekhnologiia obrazovaniia vzroslykh na osnove vitagennogo (zhiznennogo) opyta [The theory and technology of adult education based on vitagenic (life) experience]. Doctoral thesis in pedagogy. Ural State Pedagogical University, Yekaterinburg, $372 \mathrm{p}$.

Yablonskikh, Yu. P. (2006). Nravstvennoe vospitanie shkolnika kak subekta sotsialnykh otnoshenii [Moral upbringing of a schoolchild as a subject of social relations]. Ph.D. thesis in pedagogy. Orenburg State Pedagogical University, Orenburg, $178 \mathrm{p}$.

Received: 31 June 2021 | Accepted: 9 October 2021 | Published: 29 January 2022

This is an Open Access article distributed under the terms of the Creative Commons Attribution License, which permits unrestricted use, distribution, and reproduction in any medium, provided the original work is properly cited. 


\section{Appendix 1.}

\section{Questionnaire “MY PERSONAL CULTURAL EXPERIENCE?”}

Psychologists have proven that our personal life experience largely determines our personal position, attitudes toward the world, people, our behavior, the decisions we make in situations of choice...

Looking back, we can often determine for ourselves which events in our lives, which experiences have become meaningful and defining for us, which experiences have remained relevant over the years. Some experience we lack, some experience we ourselves have recognized as negative and have not taken as a guide for action. What contribution has the school, additional education, cultural institutions, the street, friends, and family made to our piggy bank of experience? Let's try to figure it out.

In the mass format, this is important for the correction of the educational and cultural environment, programs, events, etc.

The questionnaire consists of 5 questions-tasks. The format of the answer is indicated in each question-task.

Let's begin!

1. Were there any cultural institutions (theaters, museums, exhibitions, cinemas, philharmonic halls, concert halls, etc.) in your experience, visiting which remained in your memory for a long time, motivated you to some new directions of self-development, inspired your own creativity...? Mark the suitable answer with a checkmark:

- No, going to cultural institutions has always been enforced and tiresome

- With a stretch, a couple of cases can be considered inspiring and significant events

- Yes, there rarely were such events - something once every 5 years

- Yes, more or less regularly - there are a couple of cultural institutions that I enjoy visiting from time to time

- Yes, I have had many such events and institutions in my experience, some of which I have been systematically visiting over the years

- Other

If you chose one of the last $\mathbf{3}$ positions (Yes), please name a few of your favorite cultural institutions and/or motivational cultural events.

If you chose one of the first two positions (no or a couple of cases with a stretch), please rate on a 10-point scale (from 0 to 10 ) your desire to discover something new in culture - those institutions, activities that would make your life brighter, motivate you to reach new heights, be creative - approximately as follows:

$0-$ no, I don't need this, I have no time.

...

5 - average - I could try it if there were something interesting.

...

10 - for sure - 100 percent - this area was closed to me, but I intend to change that and discover it for myself.

Thus, your estimation of your intentions in points:

2. What did the pandemic bring to your cultural experience? Check the box next to the 


\section{fitting answer}

- Nothing new: did not go to museums/theaters, same as before

- The restrictions during the pandemic simply blocked my cultural life, no new experiences, that is, only negative - a sort of vacuum

- The pandemic did limit my cultural life, but not to $100 \%$ - despite the pandemic, I managed to get a little experience of visiting cultural institutions and events, some of which were significant

- The pandemic did not interfere with my active cultural life - I had excursions to cultural sites and trips and participated in events $-\mathrm{a}$ lot of interesting things that enriched my personal experience

\section{ADDITIONAL QUESTION - choose "yes" or "no"}

During the pandemic, I had new cultural experiences in virtual space - for example, I discovered virtual tours of museums in foreign countries, attended events in Zoom, etc.

YES/NO?

3. Try to estimate what cultural experience of yours has most influenced the way you are, your attitude toward the world, people, yourself, your choice of profession, your worldview, your hobbies, etc. What experience was the most significant? Estimate the significance of the experience in points from 0 (did not happen or did not matter) to 10 (up to a very high degree of significance)

Rate the significance of this experience in points from 0 to 10 - that is, choose from: 1-2-3-4-5-6-7-8-9-10.

- Reading books

- Visiting theaters

- Visiting museums

- Going to concerts

- Excursions - trips across Russia, excursions around my city/region with visits to cultural sites

- Excursions - trips to foreign countries with visits to cultural sites

- Experience of my own performances at concerts and festivals, at school, in the Palace of Children's and Youth Creativity, and on other stages

- Experience of my personal participation in creative competitions

- Virtual excursions to museums, exhibitions

- All culture on the Internet - books, movies, music, theaters, information about cultural objects

- Anything else - add your options

Surely you must have something to add to the list - please add a word or two about the most significant cultural experience - give some examples or your other perspective on that experience

4. A question about the types of experiences of your school years (specifically school years and not just the experience within the school!). What kinds of experiences did you manage to collect during your school years - answer by checking one of the numbers:

0-1-2-3-4-5-6-7-8-9-10 (that is, rate the amount/significance of such experiences)

Types of experiences 
0-1-2-3-4-5-6-7-8-9-10

- Experience performing on the stage of the school hall or the Palace of Children's and Youth Creativity as a host of a mass event (school-wide or for several classes, etc., festivals, contests, evenings)

- Experience performing a role in a play/staging on the stage of a school hall or the Palace of Children's and Youth Creativity

- At least 3 years of experience studying at a music/art school

- At least 1 year of experience in creative clubs, extracurricular studios at school, or other institution

- Experience of participation in creative competitions, Olympiads, presentation of your creative works at exhibitions (musical, dance, art, etc.) at school, the Palace of Children's and Youth Creativity, or other organizations

- Experience of winning (!) creative competitions, Olympiads, presentation of your creative works at exhibitions (music, dance, art, etc.) at school, the Palace of Children's and Youth Creativity, or other organizations - from the title of laureate to 1st place

- Experience of participating in creative events at school, the Palace of Children's and Youth Creativity, or other organizations as a member of the audience

- Experience of working in a team of creative event organizers at school, the Palace of Children's and Youth Creativity, or other organizations as a member of the audience

- Experience in creating creative media products and presenting them on the Internet

- Experience of participating in discussions of books read, in debates, presentations of your creative works based on literary works at school, the Palace of Children's and Youth Creativity, or other organizations

- Experience of going to theaters/museums/concerts and other cultural events with the whole family (first of all, with parents)

- Experience going to theaters/museums/concerts and other cultural events with the entire school class

- Experience going to theaters/museums/concerts and other cultural events with friends other than classmates

- Experience of long trips with visits to cultural sites with parents, family

- Experience of long school trips with visits to cultural sites

- Experience presenting creative abilities/achievements to friends outside of school and other organizations - in the neighborhood, at home, etc.

- Experience of ??? (add your options)

5. The last task, almost creative: Please make your own list of your cultural experiences (any amount, you can add more rows) that were or are significant for your development, social growth, attitude to the world, that motivate your creativity, possibly the choice of profession, that have affected your personality.

But this time, one complicating condition: Unlike the lists above, this list must be as specific as possible - if it is books, which ones, if it is theatres, where, if it is trips, to which cultural sites, if it is visits to creative classes, where and what kind of, etc. Thus, your own list of your cultural experiences:

\begin{tabular}{|l|c|}
\hline Types of experience & $\begin{array}{c}\text { Where did you get this } \\
\text { experience? }\end{array}$ \\
\hline
\end{tabular}




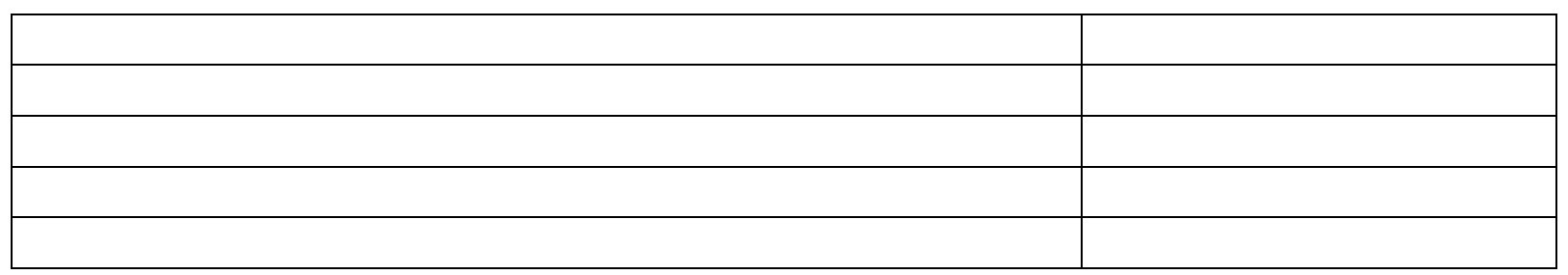

And a little bit about yourself.

How old are you? ___ Your gender: male/female (underscore). Year of study: Oblast City/district

Thank you for participating in the study! We hope that this "revision" of your own experience helped you discover something new about yourself and motivated you to add to your lists! Good luck! 